Weed Research, Japan Vol. 31 (2) 157 163 (1986)

雑草研究

\title{
Mode of Herbicidal and Selective Action of DPX-F5384 between Rice and Weeds*
}

\author{
Shunji Takeda, David L. Erbes**, Philip B. Sweetser**, \\ James V. HAY** and Takeshi YUYAMA \\ Agricultural Products Division, Du Pont Japan Limited, Tokyo, Japan \\ **Agricultural Products Department E.I. du Pont de Nemours \\ and Company, Inc. Wilmington, Delaware 19898
}

\section{Introduction}

Londax ${ }^{\circledR}$ (trade name of DPX-F5384) is a new broad spectrum herbicide for paddy rice. DPX-F5384 (methyl 2-[[[[[ (4,6-dimethoxypyrimidin-2-yl) amino] carbonyl] amino] sulfonyl] methyl]benzoate), the active ingredient, is highly effective for control of most annual and perennial broadleaf weeds and sedges. Other papers in this series describe these properties in detail ${ }^{6,7)}$.

Both DPX-F5384 and chlorsulfuron (2-chloro$N$-[ (4-methoxy-6-methyl-1,3,5-triazin-2-yl)aminocarbonyl]benzenesulfonamide) are herbicidal sulfonylureas. The primary site of action for chlorsulfuron is the inhibition of acetolactate synthase, an enzyme in the pathway for the biosynthesis of branched-chain amino acids ${ }^{3)}$. Secondary effects include the cessation of DNA synthesis, cell division and plant growth" Plants such as wheat and nightshade tolerate chlorsulfuron because of their abilities to metabolize the herbicide to metabolites which are relatively weak inhibitors of acetolactate synthase ${ }^{1,2,5)}$. In this paper we demonstrate that DPX-F5384 also inhibits acetolactate synthase and branched-chain amino acid biosynthesis and that rice plants can metabolically inactivate this compound.

\section{Materials and Methods}

\section{Compounds}

Radioactive DPX-F5384 was synthesized by New England Nuclear Corp. with ${ }^{14} \mathrm{C}$ labels in the phenyl ring $(29.8 \mu \mathrm{Ci} / \mathrm{mg})$ and the pyrimidine ring $(16.6 \mu \mathrm{Ci} / \mathrm{mg})$. Metabolite I of DPXF5384 in plant was synthesized by a two-step sequence. Coupling of 2-(methoxy-carbonyl) phenylmethylsulfonylisocyanate with 4-benzyloxy-6-methoxypyrimidin-2-amine in methylene chloride gave the 4-benzyloxy-6-methoxypyrimidin-2-yl analog of DPX-F5384. Hydrogenolysis ( $5 \% \mathrm{Pd}-\mathrm{C}, \mathrm{THF}$ ) of the benzyloxy analog gave metabolite $\mathrm{I}, \mathrm{mp} 210 \sim 215^{\circ}$ (d).

\section{Rice plants}

The metabolism studies and special studies were made with Japonica rice, varieties M-101 and Nihonbare. The rice was grown in a greenhouse $\left(28 \pm 4^{\circ} \mathrm{C}\right.$ days, $21 \pm 4^{\circ} \mathrm{C}$ nights) to the 2 to 2.5 leaf stage. The plants were transferred to controlled environment growth rooms (24士 $2^{\circ} \mathrm{C}$ days, $20 \pm 1^{\circ} \mathrm{C}$ nights; $16 \mathrm{hr}$ days) one to three days prior to the metabolism studies.

\section{Metabolism studies}

a. Uptake of ${ }^{14} \mathrm{C}-\mathrm{DPX}-\mathrm{F} 5384$

Metabolism studies with DPX-F5384 were made on excised leaves of rice plants at the $2 \sim 3$ leaf stage. The rice leaves were cut under water and the cut ends quickly placed in $20 \mathrm{ml}$

* A part of the work was presented at the 10th conference of the Asian-Pacific Weed Science Society, 1985 and at the British Crop Protection Conference-Weeds, 1985. 
vials containing $2 \mathrm{ml}$ of $2 \mathrm{ppm}{ }^{14} \mathrm{C}-\mathrm{DPX}-\mathrm{F} 5384$ (made up in 1/4X Hoagland's nutrient solution). The leaves were removed from the vial after allowing one hour uptake, washed and the cut ends placed in $20 \mathrm{ml}$ vials containing $5 \mathrm{ml}$ of $1 / 4 \mathrm{X}$ Hoagland's solution. After one to six hours, the leaves were washed with distilled $\mathrm{H}_{2} \mathrm{O}$, frozen in liquid $\mathrm{N}_{2}$, and stored at $-80^{\circ} \mathrm{C}$ until the extraction step. The frozen leaves were extracted with $80 \%$ cold acetone as described by Sweetser et al. ${ }^{2,5}$. A similar procedure was used for the metabolism of DPXF5384 by the leaves of weeds.

b. High-performance liquid chromatography (HPLC) of plant extracts

HPLC separations of the DPX-F5384 metabolites, acid hydrolysis products, and unmetabolized DPX-F5384 were made with a Du Pont model 850 liquid chromatograph and a Du Pont Zorbax ${ }^{\circledR}$ ODS column $(6.2 \times 250 \mathrm{~mm})$. The chromatography conditions were: Mobile phase $\mathrm{A}=\mathrm{H}_{2} \mathrm{O}+0.1 \%$ formic acid; $\mathrm{B}=$ acetonitrile + $0.1 \%$ formic acid; with a non-linear concave gradient of $5 \% \mathrm{~B}$ to $100 \% \mathrm{~B}$ in 30 minutes; flow $2.7 \mathrm{ml} / \mathrm{min}$.; temperature $35^{\circ} \mathrm{C}$. The distribution of radioactivity from the HPLC column was followed by collecting 0.5 to 1.0 $\mathrm{ml}$ fractions of the eluant directly into scintillation vials and the ${ }^{14} \mathrm{C}$ activity determined by scintillation counting.

Semipreparative amounts of the major rice metabolite were isolated from the acetone extracts of the rice leaves by first removing the acetone on a rotating evaporator, adjusting the $\mathrm{pH}$ of the aqueous solution to 7.0 and extracting twice with equal volumes of $\mathrm{CH}_{2} \mathrm{Cl}_{2}$. The $\mathrm{pH}$ of the aqueous solution was lowered to 3.0 and extracted three times with equal volumes of $\mathrm{CH}_{2} \mathrm{Cl}_{2}$. The $\mathrm{pH} 3.0 \mathrm{CH}_{2} \mathrm{Cl}_{2}$ extracts were combined and taken to dryness under $\mathrm{N}_{2}$. The residue from the combined $\mathrm{CH}_{2} \mathrm{Cl}_{2}(\mathrm{pH}$ 3.0 ) extracts were made up in $20 \%$ acetonitrile and the DPX-F5384 metabolite collected with isocratic HPLC conditions of $20 \%$ acetonitrile $+0.1 \%$ formic acid.

\section{Preparation and assay of acetolactate synthase}

The leaves from ten day old etiolated rice (M101) and other plants were used as a source of acetolactate synthase. The enzyme was prepared by the same method Ray used for etiolated pea shoots ${ }^{3}$.

The assay procedure of Ray was used except that the concentration of $\mathrm{MgCl}_{2}$ was $1 \mathrm{mM}$ and $50 \mathrm{mM}$ HEPES buffer ( $\mathrm{pH} 7.5)$ replaced the phosphate buffer ${ }^{3)}$.

\section{Herbicidal activity of metabolite I of} DPX-F5384

The test was carried out using $100 \mathrm{~cm}^{2}$ plastic pots filled with Arakida soil (alluvium clay loam, organic matter $=1.2 \%$ ). After adding fertilizer (N,K,17-17, $0.5 \mathrm{~g} / \mathrm{pot})$, the seeds of rice and weeds listed in Table 5 were sown into the top soil ( $3 \mathrm{~mm}$ depth) and water was introduced to a depth of $3 \mathrm{~cm}$.

Both metabolite I and DPX-F5384 (acetone solution) were applied at early postemergence to the rice and weeds (emerging 0.5 leaf stage). Each treatment including untreated check was replicated two times. Thereafter, the pots were placed in a greenhouse until the final investigation.

Herbicidal activity was evaluated by $0 \sim 10$ rating scale ( $0=$ no effect, $10=100 \%$ killed) after 4 weeks of application.

6. Reversal of DPX-F5384 inhibition in pea roots

Pea roots were prepared and grown under conditions described by $\mathrm{Ray}^{3}$. DPX-F5384 was present in the culture flasks at $5 \mathrm{ppb}$. Valine and isoleucine levels were $100 \mu \mathrm{M}$ each.

\section{Resutls}

Reversal of DPX-F5384 inhibition by valine and isoleucine

DPX-F5384 (5 ppb) inhibited the growth of excised pea roots by $76 \%$ (Table 1 ). The addition of both valine and isoleucine $(100 \mu \mathrm{M}$ each) reversed the inhibition by DPX-F5384. 
Table 1. Reversal of DPX-F 5384 growth inhibition in pea root tips by valine plus isoleucine

\begin{tabular}{lc}
\hline Condition & $\begin{array}{c}\text { Average net root growth } \\
(\mathrm{mm})\end{array}$ \\
\hline Control & $37.2 \pm 3.0$ \\
$\begin{array}{l}\text { Valine plus isoleucine } \\
(100 \mu \mathrm{M} \text { each })\end{array}$ & $30.8 \pm 3.9$ \\
$\begin{array}{l}\text { DPX-F5384 (5 ppb) } \\
\text { DPX-F5384 plus valine } \\
\text { plus isoleucine }\end{array}$ & $8.8 \pm 1.8$ \\
\hline
\end{tabular}

Metabolism of DPX-F5384 by rice and weeds

The metabolism of DPX-F5384 by rice laves was very rapid compared to that of sensitive weeds. A plot of the $\log$ of unmetabolized DPX-F5384 in a leaf vs. time followed pseudo first order kinetics from which a metabolic half-life of the herbicide was calculated (Figure 1). The comparative metabolism of DPX-F5384 by leaves of rice and some sensitive and tolerant weeds is outlined in Table 2 . Weeds sensitive to DPX-F5384 show little or no metabolism of DPX-F5384 at the levels tested. Barnyardgrass, which has intermediate tolerance to DPX-F5384, showed an intermediate metabolism, while the more tolerant sprangletop showed rapid metabolism of DPXF5384.

Characterization of the DPX-F5384 metabolite in rice

Metabolism studies with $\left({ }^{14} \mathrm{C}\right.$-phenyl) and $\left({ }^{14} \mathrm{C}\right.$-pyrimidine) labeled DPX-F5384 indicate that rice leaves rapidly metabolize DPX-F5384 to one major metabolite which still contains both the phenyl and pyrimidine rings. The rice metabolite was isolated by semipreparative HPLC and characterized as the 4-hydroxy analog of DPX-F5384. These studies suggest that the metabolism of DPX-F5384 takes palce by hydroxylation of one of the methoxy groups, giving an unstable $-\mathrm{OCH}_{2} \mathrm{OH}$ intermediate which decomposes to the hydroxy pyrimidine, Metabolite I (Figure 2).

Proof of the structure of Metabolite I was the following:

A. Metabolite I gave identical HPLC reten-

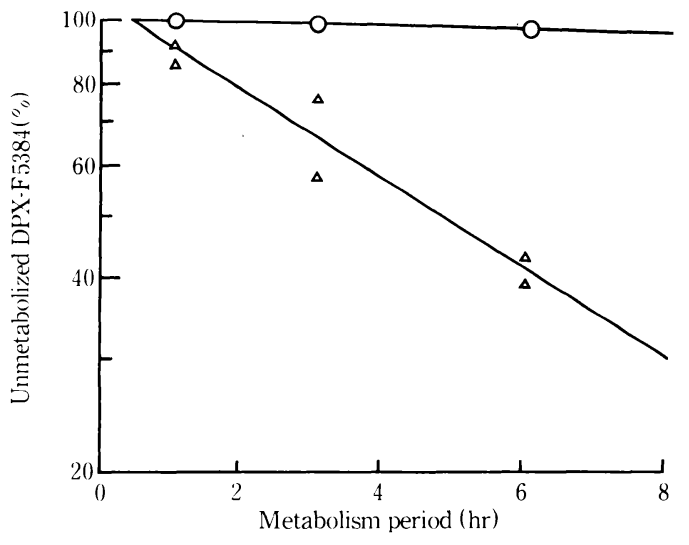

Figure 1. Metabolism of DPX-F5384 in rice and water plantain leaves. Section 3 of material and methods describes the method used in this experiment (rice, $\triangle$; water plantain, $\bigcirc$ )

Table 2. Metabolism of DPX-F5384 by rice and weed leaves

\begin{tabular}{lc}
\hline \hline \multicolumn{1}{c}{ Plant material* } & $\begin{array}{c}\text { Metabolism } \\
\text { Half-life (hours) }\end{array}$ \\
\hline Rice (Japonica M-101) & $2.6-9.0$ \\
Rice (Japonica Nihonbare) & $2.6-4.2$ \\
Rice (Indica Star Bonnette) & $1.1-5.8$ \\
Waterplantain (A. trivale) & $>50$ \\
Arrowhead (S. latifolia) & $>50$ \\
Sedge (Cyperus difformis) & $>50$ \\
Sedge (Scirpus mucronatus) & $>50$ \\
Barnyardgrass (E. crus-galli) & $12-50$ \\
Sprangletop (Leptochloa dubia) & 1.5 \\
\hline
\end{tabular}

* The age of the plants was: rice-13 to 18 days old; water plantain-28 to 34 days old; arrowhead-10 to 15 days old; sedges- 6 to 8 weeks old; barnyardgrass-14-19 days old; sprangletop-19 days old.

tion times as the authentic I on two columns and 4 different mobile phases.

B. Mass spectrum (E.I.) of Metabolite I and the authentic compound gave similar fragmented ions.

C. Acid hydrolysis of Metabolite I and the authentic compound gave the same products (2-amino-4-hydroxy-6-methoxy-pyrimidine and 2-aminosulfonylmethyl benzoic acid, methyl ester) while acid hydrolysis of DPX-F5384 gave the same benzoic acid but a different heterocycle (2-amino-4,6- 


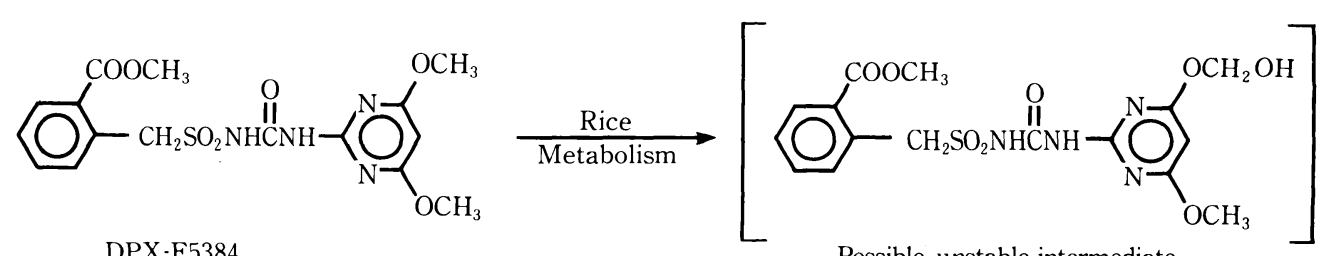

Possible unstable intermediate

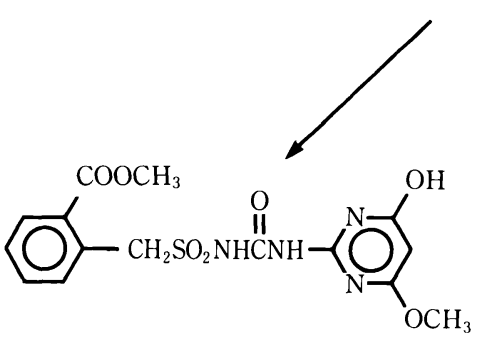

Metabolite I

Figure 2. Metabolism of DPX-F5384 by rice leaves

dimethoxypyrimidine).

Effect of DPX-F5384 on acetolactate synthase

DPX-F5384 was an effective inhibitor of the acetolactate synthases from rice, barnyardgrass, Cyperus, and peas (Table 3). Fifty per cent inhibition in the $30 \mathrm{~min}$ fixed time assay was reached with 7 to $25 \mathrm{ppb}$ DPX-F5384. By contrast, the metabolite of DPX-F5384 produced by rice produced $50 \%$ inhibition at 19900 ppb (Table 4).

Table 3. Effect of DPX-F5384 on the acetolactate synthase from several plants

\begin{tabular}{lr}
\hline \hline Source of acetolactate synthase & \multicolumn{1}{c}{$\mathrm{I}_{50}(\mathrm{ppb})$} \\
\hline Japonica rice (M101) & $6.9 \pm 0.7$ \\
Barnyardgrass & $8.8 \pm 2.5$ \\
Cyperus esculentus & $9.5 \pm 1.3$ \\
Pea (Alaska) & $24.7 \pm 6.4$ \\
\hline
\end{tabular}

Table 4. I 50 values (rice acetolactate synthase) for DPX-F5384 and metabolite I from rice

\begin{tabular}{lc}
\hline \hline Compound & $\mathrm{I}_{50}(\mathrm{ppb})$ \\
\hline DPX-F5384 & $6.9 \pm 0.7$ \\
Metabolite I & $19900 . \pm 5100$. \\
\hline
\end{tabular}

Table 5. Plant response to metabolite I of DPX-F5384

\begin{tabular}{lrrrrrrrr}
\hline \multirow{2}{*}{ Compound } & \multirow{2}{*}{$\begin{array}{c}\text { Rate } \\
\text { g a.i./ha }\end{array}$} & \multicolumn{6}{c}{ Herbicidal activity } \\
\cline { 3 - 9 } & & Rice & Eo & Cd & Mv & Sj & Bl \\
\hline Metabolite I & 2000 & 0 & 0 & 0 & 0 & 0 & 0 \\
& 4000 & 0 & 0 & 0 & 0 & 0 & 0 \\
DPX-F5384 & 25 & 1 & 4 & 10 & 10 & 8.5 & 10 \\
\hline
\end{tabular}

Rating: $0-10$ scale

Rice: Nihonbare,

Eo: Echinochloa oryzicola, $\mathrm{Cd}$ : Cyperus difformis, $\mathrm{Sj}$ : Scirpus juncoides, Mv: Monochoria vaginalis, $\mathrm{Bl}$ : Annual broadleaves

\section{Herbicidal activity of metabolite I of DPX-F5384}

As shown in Table 5, plant response studies with the metabolite I indicated that it was not herbicidally active up to $4000 \mathrm{~g}$ ai/ha while DPX-F5384 even at $25 \mathrm{~g}$ a.i./ha provided high herbicidal activity on sensitive weeds in the paddy.

Effect of several sulfonylureas on rice acetolactate synthase

TAKEDA et $a l .^{6}$ ) found that sulfonylureas with an $-\mathrm{O}$ - or $-\mathrm{CH}_{2}$ - bridge between the sulfonyl moiety and the aryl group (DPX-R5582, DPXF5390 and DPX-F5384) were selective toward rice while those without this spacer group 
Table 6. $I_{50}$ values for several sulfonylureas on rice acetolactate synthase

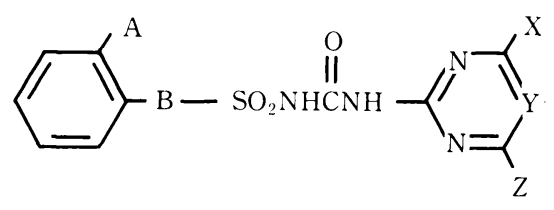

\begin{tabular}{|c|c|c|c|c|c|c|}
\hline Sulfonylurea & $\mathrm{A}$ & $\mathrm{B}$ & $\mathrm{Y}$ & $\mathrm{X}$ & $Z$ & $\mathrm{I}_{50} \quad(\mathrm{ppb})$ \\
\hline DPX-W 4189 & $\mathrm{Cl}$ & - & $\mathrm{N}$ & $-\mathrm{OCH}_{3}$ & $-\mathrm{CH}_{3}$ & $11.9 \pm 1.3$ \\
\hline DPX-T 6376 & $-\mathrm{COOCH}_{3}$ & - & $\mathrm{N}$ & $-\mathrm{OCH}_{3}$ & $-\mathrm{CH}_{3}$ & $6.7 \pm 2.0$ \\
\hline DPX-W4515 & $\mathrm{Cl}$ & - & $\mathrm{C}$ & $-\mathrm{OCH}_{3}$ & $-\mathrm{OCH}_{3}$ & $1.5 \pm 0.5$ \\
\hline DPX-F 5390 & $\mathrm{Cl}$ & $-\mathrm{CH}_{2}^{-}$ & $\mathrm{C}$ & $-\mathrm{OCH}_{3}$ & $-\mathrm{OCH}_{3}$ & $441.0 \pm 93.0$ \\
\hline DPX-R 5582 & $\mathrm{Cl}$ & $-\mathrm{O}$ & $\mathrm{C}$ & $-\mathrm{OCH}_{3}$ & $-\mathrm{OCH}_{3}$ & $2.5 \pm 0.8$ \\
\hline DPX-T 6375 & $-\mathrm{COOCH}_{3}$ & - & $\mathrm{C}$ & $-\mathrm{OCH}_{3}$ & $-\mathrm{OCH}_{3}$ & $2.4 \pm 0.2$ \\
\hline DPX-F 5384 & $-\mathrm{COOCH}_{3}$ & $-\mathrm{CH}_{2}-$ & $\mathrm{C}$ & $-\mathrm{OCH}_{3}$ & $-\mathrm{OCH}_{3}$ & $6.9 \pm 0.7$ \\
\hline DPX-R 6514 & $-\mathrm{COOCH}_{3}$ & $\cdot \mathrm{O}$ & $\mathrm{C}$ & $-\mathrm{OCH}_{3}$ & $-\mathrm{OCH}_{3}$ & $1.5 \pm 0.5$ \\
\hline
\end{tabular}

The acetolactate synthase from etiolated shoots of M101 rice was partially purified by ammonium sulfate precipitation ( 25 to $50 \%$ cut) and assayed with the sulfonylureas for $30 \mathrm{~min}$. at $\mathrm{pH} 7.5$ with $1 \mathrm{mM} \mathrm{MgCl}_{2}, 0.5$ $\mathrm{mM}$ thiamin pyrophosphate, $20 \mathrm{mM}$ pyruvate, and $10 \mu \mathrm{M}$ flavin adenine dinucleotide.

(DPX-W4515 and DPX-T6375) exhibited very low or no selectivity. With the exception of DPX-F5390, all of these compounds are very effective inhibitors of rice acetolactate synthase (Table 6).

\section{Discussion}

DPX-F5384 strongly inhibits the growth of excised pea roots at $5 \mathrm{ppb}$ (Table 1). This inhibition is reversed by the addition of valine and isoleucine suggesting that the primary site of DPX-F5384 action may be the inhibition of the biosynthesis of branched-chain amino acids. This idea is further supported by the observation that DPX-F5384 inhibits acetolactate synthase from peas at the ppb level (Table 3). DPX-F5384 is also a potent inhibitor of the acetolactate synthases from weeds associated with rice. The inhibition of acetolactate synthase can account for the her- bicidal action of DPX-F5384 in weeds.

The major factor responsible for the lack of phytotoxicity of the sulfonylurea herbicide, chlorsulfuron, to cereal crops and tolerant weeds is the ability of these plants to metabolize chlorsulfuron to inactive products ${ }^{2,5}$. Our studies on the metabolism of DPX-F5384 by rice leaves suggest that inactivating metabolism also plays an important role in the tolerance of rice to DPX-F5384 since rice acetolactate synthase is readily inhibited by this sulfonylurea (Table 3 ). The major metabolite, Metabolite I, shows very low herbicidal activity and is relatively weak as an inhibitor of rice acetolactate synthase (Table 4,5). To inhibit the rice enzyme by $50 \%$ the concentration of metabolite I must be nearly 3000 times greater than DPX-F5384. Kinetic studies on the rate of DPX-F5384 metabolism by isolated rice leaves indicates that metabolism is 
rapid. The metabolic half life of DPX-F5384 in the rice leaf ranges from $2 \sim 9$ hours depending upon the age of the leaf and the growth conditions. There is little or no metabolism of DPX-F5384 by sensitive broadleaf weeds such as water plantain (Alisma trivale) and arrowhead (Sagittaria latifolia) (Table 2).

A difference in safety on rice plants was also found among sulfonylurea compounds that are potent inhibitors of the acetolactate synthase ${ }^{6}$ ) (Table 6). The cause of such different selectivities is that sulfonylureas with spacer group seem to be more easily inactivated than those without a bridge.

\section{Summary}

DPX-F5384 is the active ingredient in the rice herbicide Londax ${ }^{\circledR}$. Growth inhibition promoted by DPX-F5384 in pea roots can be reversed by addition of valine and isoleucine, suggesting inhibition of the pathway for branched-chain amino acid biosynthesis. This compound readily inhibits an enzyme in this pathway, acetolactate synthase. Although acetolactate synthase from rice is also inhibited by DPX-F5384, the rice plant is tolerant due to its ability to metabolically demethylate DPX-F5384 to a relatively weak inhibitor of its acetolactate synthase.

Acknowledgements: The authors gratefully acknowledge the work of Robert W. REISER in obtaining and interpreting the mass spectrum of the rice metabolite, R.C. Ackerson and R.C. WeIgel for providing plant material, and Ivan Turner, Marc Ruggiero and William C. HarTENSTINE for their technical assistance.

\section{References}

1) ERBes, D.L.: Plant Physiology 75 (supplement), 49 (1984).

2) Hutchison, J.M., R. Shapiro and P.B. Sweetser: Pestic. Biochem. Physiol. 22, 243 247 (1984).

3) RAY, T.B.: Plant Physiology 75, 827 831 (1984.)

4) RAY, T.B.: Pestic. Biochem. Physiol. 17, 10 17 (1982).

5) Sweetser, P.B., G.S. Schow and J.M. Hutchison: Biochem. Physiol. 17, 18 23 (1982).

6) T TKEDA, S., T. Yuyama, R.C. ACKerson, and R.C. WEIGEL: Weed Res., Japan, 30 (4) 278 283 (1985).

7) Theeda, S., T. Yuyama, R.C. Ackerson, R.C. Weigel, R.F. SAuers, L.W. Neal, D.G. Gibian and P.K. TSENG: Weed Res., Japan, 30 (4) 284 289 (1985).

(Received October 18, 1985)

DPX-F5384 の除草作用と選択作用機構

\author{
武田俊司・湯山 猛 デュポンジャパン農薬事業部 \\ D. L. ERBES・P.B. SwEeTSER・J.V. HAY デュポン農薬事業部
}

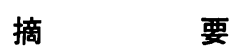

DPX-F5384 の除草作用と選択作用機構を明らかにするために，本化合物の生育阻害作用に対するバリンとインロ イシンの影響, 植物に打けるバリンとイソロイシンの生合成経路の初期段階を触媒するアセトラクテート合成酵素 （ALS）飞対する阻害，および本化合物に耐性のイネと感受性雑草における代謝について比較検討した。

1） $5 \mathrm{ppb}$ の濃度の DPX-F5384 を含む培地に，バリンとイソロイシンの各 $100 \mu \mathrm{M}$ を加え，切除したェンドウの 根を生育させた。DPX-F5384 のみの培地では, エンドウの根の生育は強く抑制されたが，バリンとインロイシンを 加えた培地では，DPX-F5384 による生育抑制はほぼ完全に解除された（Table 1)。 
2） ${ }^{14} \mathrm{C}$-phenyl と ${ }^{14} \mathrm{C}$-pyrimidine 標識 DPX-F5384 を用いて,イネと雑草の葉による代謝を検討した。イネ葉に よる本化合物の代謝は急激であり，代謝半減期はイネで $2.6 〜 9$ 時間，雑草では50時間以上を示しその差は極めて顕 著であった。さらに, イネ葉による主要な代謝物は, ピリミジン部分の 4-位のメトキシ基の水酸化によって生ずる 4-hydroxy 類縁化合物で, この代謝物の ALS に対する活性は, 親化合物の約 $1 / 3000$ 程度であり, 除草活性も $4000 \mathrm{~g}$ ai/ha の施用量で全く認められなかった。

3） DPX-F5384 はイネ, タイヌビェ, カヤツリグサおよびェンドウの ALS の働きを強く阻害した。ALS の活性 を50\%阻害する濃度は 7 25 ppb の範囲にあり, 生育抑制を示す濃度とほぼ同水準で作用した。また, 本化合物とそ の関連化合物のイネの ALS に対する影響を調べた。その結果, DPX-5390 以外のスルホニルウレア化合物は低濃度 で ALS の活性を阻害した。

4）以上の結果から，DPX-F5384 の除草作用機構は，植物の分岐鎖アミノ酸の生合成経路の初期段階に特ける酵 素, アセトラクテート合成酵素を阻害することによって, バリンとイソロイシンの生合成を妨げることを明らかにし た。さらにまた, 本化合物のイネと雑草間の高い選択性は, 両者の代謝速度の著しい差異が重要な役割を果している ことを示唆した。 